\title{
Corporate Governance in Indian perspective: A case of Grasim Industries
}

\author{
Dr. Arti Chandani ${ }^{1}$, Dr. Mita Mehta ${ }^{2}$ \\ ${ }^{1,2}$ Associate Professor, Symbiosis Institute of Management Studies, Symbiosis International (Deemed University), \\ Range Hills Road, Khadki, Pune, India
}

\begin{abstract}
It is said, "No man is an island entire of himself". We would like to apply this to the Business Organizations. The owners of any Business organization no matter how competent cannot alone bring the organization in the arena of success. A great deal of cooperation is required on part of the various stakeholders viz. the customers, suppliers, employees, shareholders and the society at large. Corporate Governance has come in vogue after 1932. All this has taken place with the tremendous growth in the size of the corporations. It is not possible for owners to keep control over every activity of the organization. Thus, the need to have specialized managers to manage the various activities has arisen. The Board is required to oversee the working of the company by its managers.
\end{abstract}

Keywords - Corporate Governance; Management of the Company

\section{Introduction}

With the evolution of Limited liability concern, the need for Corporate Governance emerged. In Limited liability Company, the ownership is separated from the management of the Company. Owners are the shareholders of the Company. They do not manage the Company; rather they appoint Board of Directors to manage the day to day activities. This has led towards the need, for the shareholder being the owner of the Company, to have a proper check on the management of the company as to how it is being managed. It is a process which makes sure that if there is a complaint then a solution is found to suit the interest of all those who are associated in any way.

It is very much required that corporations follow certain practices which will help corporation in building trust of public, thus paving a way for future growth. These practices include disclosure of financial information to all the stakeholders, a proper link between performance and remuneration, assessment of risk for the projects, clarity in strategy, policy and programme and handling of complaints/suggestions of various stakeholders.

The tem Corporate Governance came out in 1920s when there arose a need of separation of ownership and control in the corporation. Earlier sole proprietor ship and partnership were prevalent. The owners were the managers of the business and they worked in the best interest for themselves and schools to help inform resilience-based approaches to support vulnerable children.

Figure 1 shows the relationship of various stakeholders and management. There are other stakeholders also in the company viz. creditors, government, and others. But these stakeholders are better protected by their term and conditions with the company.

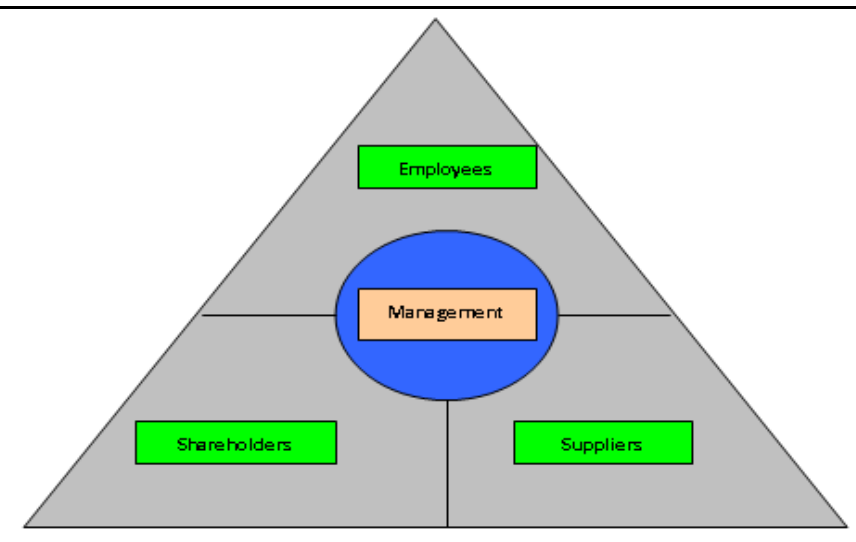

Fig.1: Corporate governance and Stakeholders

Employees, shareholders and suppliers tend to rely more on what is being told to them. So the need of corporate governance is much more for them, than any other stakeholder. Management is in the centre for obvious reason, as management has to follow corporate governance and provide information to these stakeholders periodically.

Corporate Governance is about how organizations are directed and controlled. Corporate Governance is a mechanism where interests, of not only shareholders but all other stakeholders in the company, are protected. Corporate governance has become more essential in today's times as we see more scams, fraud, malpractices being followed by the corporations. Various scams have rocked the economies, especially India, such as Demat scam, Harshad Mehta scam etc. Corporate governance does not guarantee that the scams would not take place. If corporate governance is being followed, which is an optional till date; this will ensures that there is transparency in the activities of the management.

Focus on Corporate Governance can provide a clear competitive advantage and stimulate corporate innovation. 
Corporate Governance is no more an option but an imperative for business corporations. In the era of globalization, where Indian companies are going aboard for raising funds, and FDI is taking place in India, the need for corporate governance is very obvious. Indian companies have tried to adopt the international standards and it is very much visible in the current times. This paper highlight how Indian companies have gone for corporate governance and what is the regulatory mechanism for the companies to have corporate governance. It also covers the CII desirable code of conduct, among others.

\section{Definition}

The definition given by CII Task Force is, "Corporate Governance deals with laws, procedures, practices and implicit rules that determine A Company's ability to require managerial decisions vis-à-vis its claimants-in particular, its shareholders, creditors, the state and employees. There's global consensus on the target of 'good' corporate governance: Maximizing future shareholder value. Since shareholders are residual claimants, this objective follows from the premise that in well-performing capital and financial markets, whatever maximizes shareholder value must necessarily maximize corporate value, and best satisfy the claims of creditors, employees and therefore the State."

Corporations which are well governed outperform other companies thus attracting more investors who in turn provide finance to support growth. It is, therefore, necessary for the company Board to take ultimate responsibility for the firm's adherence to high quality standards of the corporations. There are person acting in fiduciary capacity. They own shares on behalf of millions of investors. The board should make sure that it pursues its function in an unbiased manner without conflict of interest of various stakeholders.

\section{Review of Literature}

Panagiotic (2007) examined the relationship between the size of board of directors and proportion of the nonexecutive directors on the performance of banks. The sample included 58 large European banks and the period of study was 2002-2004. It was reported that the banks' profitability is negatively related to the size of the board of directors while the impact of board composition was found to be insignificant. Board independence was not related to the performance, as measured by a proxy for Tobin's Q (Adams et.al, 2012). However the board size was found to be positively related. The research was carried out with an objective to analyse the relationship between board governance and performance using a sample of banking firm data which spanned 34 years.
The banks performance is positively related to the board size (Salim et.al, 2005). It was also identified that the quadratic relationship between banks performance and board independence. It was also reported that the return on assets and return on equity first decreased and then increased in the direct proportion to the increased percentage of outside directors on the board.

Corporate houses are failing in terms of accountability part whenever question of governance has come. Mousa F. Al Manaseer (2012) stated that the board of directors is the first internal governance charged with supervision executive decisions. Cullinan and Sutton (2002) identified that the CEO and other insiders involved in $90 \%$ of the companies fraud in their sample from the year 1987 to1999. Moreover, Baysinger and Butler (1985) determined that the companies can achieve more if it includes more outsiders in the board.

\section{Need for Corporate Governance}

The dire need for Corporate Governance arose because of the various scams that invaded the capital market up to early 2000. Recently there was the Demat Scam in 2005. When we go back we come across the 1998 collapse when Harshad Mehta made a comeback by floating a website to hand out stock tips and writing columns in several newspapers by assuring them that his column would push up their circulation figures.

Still earlier in 1992 the lawlessness in the money market had been exposed when funds were allowed to be transferred with impunity from banks and corporate houses into the equity markets. Among other unfortunate things was the Enron debacle. Enron had concealed huge losses. An alarming number of frauds have been detected in various corporations.

Cadbury Committee was set in May 1991 with the objective of raising the standard of Corporate Governance and the level of confidence in financial reporting and auditing. In the Indian context there has been an upsurge need for Corporate Governance because of the scams which have taken place as a recurring feature ever since we had liberalization. Capital markets help in the internalization of an economy and if such scams happen then how can the economy flourish.

\section{Corporate Governance in India: Statutory Provisions}

The Indian Corporate Governance scene has not been up to the mark. One of the prime reasons being, the family business orientation, and here since ages. The owners in the family business have worked to fulfill their personal

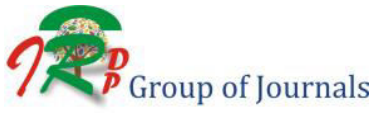


interest without caring much about all those involved. Other reason is time lag in public sector units. Other bad practices include delay in the transfer of shares, accounting juggleries and improper dissemination of information. The definition of corporate governance encompasses all the stakeholders' viz. employees, customer, suppliers etc. In order to start following the corporate governance principles, the emphasis is given that Indian companies should start with following the norms related to shareholders and the creditor. There are few reasons behind it.

- The first being that from the day, we can't start following $100 \%$. It is a gradual process which will take time. So we should start with what is more important.

- The shareholders are the owners of the companies and they provide the finance for the operations, so the first preference goes to them.

- In India, we have labour laws which are quite satisfactory in terms of protecting the interests of the shareholders. There are trade unions which also work in the interest of the employees.

Corporate governance should focus on the listed companies only. Again there are certain reasons behind it such as limited liability, big business, and so on. On 16-17 February 2006 the Indian Ministry of Company Affairs alongside the OECD organized the 2006 Policy Dialogue on Corporate Governance in India. it had been co-hosted by National Foundation for Corporate Governance; Confederation of Indian Industry; and therefore the Institute of Company Secretaries of India. The conference addressed the problems of:

- the role of the board in handling related party transactions

- The role of institutional investors in handling noncontrolling shareholders development on compliance with international accounting and auditing standards

- Corporate Governance of state owned enterprise, including the OECD guidelines on Corporate Governance of State Owned enterprise.

- Corporate governance and capital markets

- Insolvency and corporate governance

In order to promote standard of Corporate Governance, a committee was set on May 7, 1999 by SEBI under the chairmanship of Shri. Kumar Mangalam Birla. It suggested certain mandatory and non- mandatory recommendations. One of the mandatory recommendations was the meeting of the Board at least four times a year.

\section{SEBI's (Listing and Obligation Disclosure Requirement) Regulations, 2015}

This has been effective from 01st December, 2015. These Regulations prescribe different Disclosure Requirements for various sorts of listed securities. The regulations are applicable on listed entities who have listed their any of the subsequent designated securities on recognized stock exchange.

- Specified securities listed on main board or SME Exchange etc.

- Non-convertible debt securities, non-convertible redeemable preferred stock, perpetual certificate of indebtedness, perpetual non-cumulative preference shares;

- Indian depository receipts;

- Securitised debt instruments;

- Units issued by mutual funds;

- Any other securities as may be specified by the Board.

This requires that all the entities which are having securities listed on the exchanges should abide by the regulations in accordance with principles. The information which is prepared and disclosed has been done in accordance with the standards of accounting and financial disclosure. It is also to be ensured that there is no misrepresentation of information to the exchange and to the investors. The entity should also ensure that the information presented is as per the accounting standards and is implemented in letter and spirits. The accounts should also be audited annually by an agency which is independent and competent auditor.

It is also to be ensured that the knowledge is provided during a timely manner to the exchanges and individuals. The Channels for disseminating information shall provide for equal, timely and price efficient access to relevant information by investor.

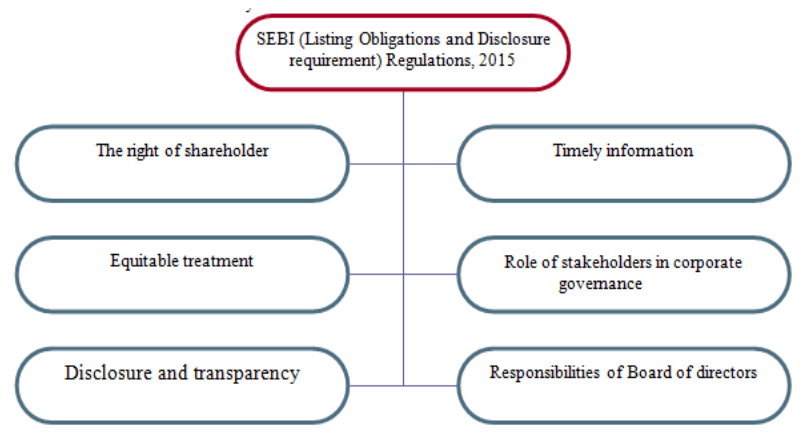

Fig.2: Corporate Governance Provisions

This can be based on two theories which are explained hereon. Shareholder Theory argues that the main task of management is to maximize shareholder returns. The proponent of Shareholder theory considers that the recital of the entire economic system can be improved if the company is run to increase shareholder value, However, in 1984, Freeman presented Stakeholder Theory that begins with the assumption that values are part of business activities .Stakeholder Theory concentrate on all party's interests, such as customers, suppliers, and communities 
since they can be affected by the success or failure of a corporation. Moreover, the successful implementation of corporate governance cannot be explicated by one theory, it is the best to merge theoretical variations.

\section{The Rights of Shareholders}

The basic premise this is the protection of the rights of shareholder hence the corporate governance framework that is established must be such that it seeks to protect the rights of the shareholders which include being informed about the meetings of the company on a timely basis, voting rights during the general shareholders meetings, Election of the members of the board, Share in the profits of the companies. It should have adequate mechanism to address the grievances of the shareholders. The shareholders should also have an opportunity to ask questions to board of directors, to place items on the agenda of general meetings. It must seek to protect the rights of the minority shareholders, Timely and accurate disclosure on all material matter whether financial or nonfinancial and access to important documents of the corporation. As per a study conducted in a research paper, about $93 \%$ of the respondents felt that minority shareholders rights are neglected in most organizations and only $7 \%$ feel that the decisions are made in their best interest.

\section{Equitable Treatment}

The entity should treat all the shareholder, including minority shareholder and foreign shareholders in an equitable manner. This implies that all the shareholders of the same series are treated equally. The entity should facilitate that the foreign shareholders are able to vote. There should be proper ways and mechanism to ensure that there is no insider trading. The entity should facilitate effective shareholder participation in major corporate governance decision including nomination and election of board of director. The entity should also facilitate voting by shareholder and it should not be very expensive to cast votes.

\section{Disclosure and Transparency}

Corporations are supposed to disclose all the material information pertaining to areas such as financial information, governance, ownership and performance and they are supposed to follow a proper channel to do so as well as do it in a timely manner. It is the responsibility of the Director to ensure maximum transparency. As per the study mentioned previously, $87 \%$ employees feel that the standards are medium or low and only $13 \%$ feel that they are high. The entity should prepare and disclosure information which is in accordance with the prescribed standard of accounting. The channels with the knowledge is being disseminating should also provide for equal, timely and price efficient access to the relevant information by users. The entity should also maintain minutes of meeting including recording dissent.

\section{Timely information}

The information should be adequate and timely to the shareholders. Each entity should give timely information about the general meetings and it should give the date, location of the meeting along with agenda of the meeting. It should also give information pertaining to capital structures and arrangement which will enable certain shareholder to obtain a degree of control disproportionate to their equity ownership. The information should also be provided to all the series and classes of shares which should be given to the investor before they can acquire shares.

\section{Role of Stakeholders in Corporate Governance}

This is the part wherein stakeholders are encouraged to understand their rights and corporations are asked to ensure maximum employee participation wherein stakeholders have to be given the right information at all times to be able to participate in the corporate governance process and they have the right to be redressed if in case of any grievance (Creditors can take it up to BIFR, CLB, civil and high court and employees can take up the matter to civil and high court. A whistle blowing mechanism has to be set in place in the organization. As per the same study, $60 \%$ of the respondents are of the opinion that the regulations are not enough and $40 \%$ are satisfied Stakeholders shall have the chance to get effective redress for violation of their rights. Stakeholders shall have access to relevant and reliable information on regular basis to enable them to participate in corporate governance process. The listed entity shall devise an efficient whistle blower mechanism enabling stakeholders, including individual employees and their representative bodies, to freely communicate their concerns about illegal or unethical practices.

\section{Responsibilities of the Board}

The Board is responsible for making changes in policies as and when required and ensuring that the people on the board are knowledgeable and ethical as well as maintain diversity, they are responsible for ensuring the alignment of corporate strategies to the goals as well as other responsibilities such as overseeing disclosures process etc. They are basically to act as a body which supervises and takes the onus for establishing excellent corporate governance and in turn be good corporate

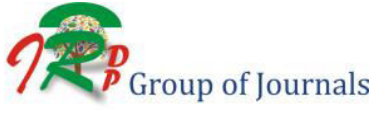


citizens. The information should be disclosed about members of board of director and key managerial personnel, if they have any material interest in any transaction or matter with the entity.

\section{SEBI Listing Obligations and Disclosure Requirements (Amendment) Regulations, 2018}

SEBI Listing Obligations and Disclosure Requirements (Amendment) Regulations, 2018 SEBI released, SEBI (Listing Obligations and Disclosure Requirements) (Amendment) Regulations, 2018 in May, 2018. There have been suggestions given by a committee which was constituted for corporate governance amendments under the chairmanship of Mr. Uday Kotak. The SEBI also issued a circular on 10 May 2018 for implementation of certain recommendations of the Kotak Committee. There have been 81 recommendations, with an objective to enhance corporate governance, given by the Kotak Committee on the followings:

- Improving the role, composition and effectiveness of the board and its committees, including evaluation practices

- Ensuring independence within the spirit of Independent Directors and their active participation within the functioning of the corporate

- Improving safeguards and disclosures concerning Related Party Transactions

- Improving transparency in accounting and auditing practices by the listed companies

- Addressing issues faced by investors on voting and participation generally meetings

- Enhanced monitoring of group entities

- Disclosure and transparency related issues, if any

SEBI's Corporate Governance Amendments reflects SEBI's acceptance of 42 recommendations made by the Kotak Committee, out of which 14 recommendations were accepted with modifications either to scope of its application, or expected timeline for its implementation. SEBI decided to refer eight recommendations to varied agencies (i.e., government, professional bodies, other regulators, etc.), considering that the matters involved relate to them. Remaining 31 recommendations weren't accepted. the present corporate governance practices of the Indian listed corporate entities, where still a sizeable number of such entities are promoter-led, are on the verge of evolution with these Corporate Governance Amendments. These amendments pave how for aligning with a number of the simplest practices followed globally and convey during a renewed specialise in improved corporate governance by way of higher structure, more rigorous checks and balances and greater independence of all key gate-keepers including boards and auditors.

\section{SEBI's Code of Corporate Governance}

Corporate Governance is no more an optional aspect. It has become a necessity for the corporations now, though not statutory. This can be proven by the fact that according to SEBI Code of Corporate Governance, all the listed companies have to include a separate section of Corporate Governance in their reports. Items to be included in the list are as under,

- A brief statement on Corporation's philosophy on code of governance.

- Board of Directors - This should include composition and category of Directors, attendance of Directors, Number of Board of Director's meetings held and also the number of other Board Committees of which the Director is a member of. It is necessary to know the latter aspect because if the Director is a member of several Board Committees then there is a possibility of clashing interest between them. A single person should not hold directorship in more than ten listed companies.

- Audit Committees - It is a watch dog of the company Governance. "It acts as a bridge between the Board of the Statutory Auditors and Internal Auditors." This committee audits various relevant aspects just like the attendance within the meetings during the year. There should be a minimum number of meetings which the members should be made to attend. This committee keeps a record of the name of the members and therefore the chairperson alongside a quick description of the terms of reference.

- Remuneration Committee - It should contain a remuneration policy with detail of remuneration to all directors, as per the format in the main report and attendance during the year.

- Share holder committee - It is to be made to keep into account the number of shareholder complaints received and the problems which are not solved. It also keeps record of number of pending shares and the number of Non-executive directors heading the committee.

- General Body Meeting - A record of location and time of the earlier Annual General Meetings has to be maintained along with the procedure for Postal Bullet.

- Disclosure - It visualizes disclosures on materially significant party related transaction with its promoters, Directors and Management.

- Means of Communication - It includes half yearly report sent to each household of shareholder and record quarterly results.

- General Shareholder Information - General Information includes Annual General Meeting, Financial Calendar, Date of Book closure, date for dividend payment and listing on stock exchanges.

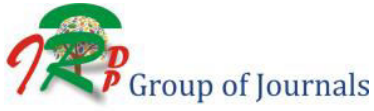




\section{Corporate governance: Desirable Provisions}

In April, 1998, Confederation of Indian industry (CII) set up the desirable code of corporate governance. This was done under the chairmanship of Mr. Rahul Bajaj. This code tries to stipulate the desirable action on the part of the company management so that it practices transparency, fairness and integrity in its operations. It covers the following:-

\subsection{Board of Directors}

- Inclusion of non-executive as the independent board of directors, if the turnover is more than 100 crores

- Two tier board system

- Maximum no. of directorship should be limited to 10 companies

- Independent directors should become the active members of the boards

- Non executives should be a fee which is over and above a sitting fee.

\subsection{Desirable Disclosure}

- Director's fee and remuneration

- Key information of business division and segments

- A detail break of funds obtained from public

- Disclosure of foreign currency transaction

- High and low of monthly average of share price of stock exchange where the company is listed

- Disclosure on debt exposure of the company should be strengthened

- Stock exchange should insist upon the compliance certificate signed by CEO and CFO accepting the management responsibility for the preparation of the financial statements.

\subsection{Creditor's Rights}

- Strict norms for companies who default on fixed deposits

- Credit rating information must be disclosed

\subsection{Capital Market Issues}

- Government must allow for greater funding to the corporate sector against the security the share and paper.

\subsection{FIs and Nominee Director}

- FI should take a policy decision to withdraw from board of companies where there individual shareholding is $5 \%$ or less or total FI holding is under $10 \%$.

\subsection{Data Analysis: Grasim Industries}

Grasim industries which is part of Aditya Birla Group, was incorporated in 1947 and is based in Mumbai. It is Flagship Company of the Aditya Birla Group. it's the most important producer of viscose Fiber (VRF) globally and largest exporter of VRF of India. It exports to quite 50 countries. The Aditya Birla Group may be a leading global player in VSF, accounting for $~ 17$ per cent of worldwide production. Over the years, the company has strengthened backward integration in dissolving grade pulp, caustic soda, power and steam - major inputs required for the production of VSF. Grasim is India's initiate in viscose staple fibre (VSF), a man made, and biodegradable fibre with distinctiveness akin to cotton. An extremely versatile and easily blend able fibre, VSF is widely used in apparels, home textiles, dress material, knitted wear and non-woven applications. Grasim's VSF plants are located at Nagda in Madhya Pradesh, Harihar in Karnataka and Kharach in Gujarat with an aggregate capacity of 333,975 tpa.

Its consolidated net revenue was Rs. 562 billion (US\$8.6 Bn.) and consolidated net profit of Rs37 billion (US\$ 565 Mn.) in FY 2018.

Grasim industries have won many awards nationally and globally and some of which are:-

- Dun \& Bradstreet Corporate award 2018 is for textile sector stellar performance.

- Grasim is ranked at 1,380 by Forbes magazine in its listing of the "Forbes 2000 Best companies"

- Grasim is ranked $2^{\text {nd }}$ for Best Corporate governance practices in Asis-pacific by IR Global ranking.

\subsection{Corporate governance at Grasim}

Grasim Industries Limited is committed to the adoption of best governance practices and its adherence within the true spirit, in the least times. Their governance practices are self-driven, reflecting the culture of the trusteeship that's deeply ingrained in our worth system and reflected in our strategic growth process. Governance philosophy rests on five basic tenets, viz.

- Board accountability to the corporate and stakeholders

- Equitable treatment to all or any shareholders

- Strategic guidance and effective monitoring by the Board

- Protection of minority interests and rights

- Transparency and timely disclosure

In line with the above philosophy, Grasim continuously strives for excellence through adoption of best governance and disclosure practices.

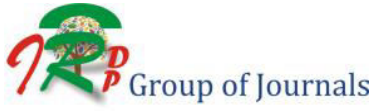




\section{Data Pointers (FY 2016-17)}

Table 1: Various data point of Grasim Industry

\begin{tabular}{|c|c|c|}
\hline Area & Grasim & Remarks \\
\hline $\begin{array}{l}\text { No. of board } \\
\text { meetings }\end{array}$ & 5 & $\begin{array}{l}\text { Grasim had adequate } \\
\text { number of meetings and the } \\
\text { information was } \\
\text { disseminated at proper time } \\
\text { and the details of attendance } \\
\text { are furnished in the Annual } \\
\text { report. }\end{array}$ \\
\hline $\begin{array}{l}\text { Whistle } \\
\text { blowing } \\
\text { mechanism }\end{array}$ & Yes & $\begin{array}{l}\text { Grasim has a whistle } \\
\text { blowing mechanism in place } \\
\text { and this seeks to protect the } \\
\text { stakeholder's rights }\end{array}$ \\
\hline $\begin{array}{l}\text { Stakeholder's } \\
\text { Relationship } \\
\text { Committee }\end{array}$ & Yes & $\begin{array}{l}\text { Redressal mechanism for } \\
\text { stakeholders is in place }\end{array}$ \\
\hline $\begin{array}{l}\text { Dividend } \\
\text { Distribution } \\
\text { Policy }\end{array}$ & Available & $\begin{array}{l}\text { Grasim's has mentioned that } \\
\text { dividends will be provided } \\
\text { to shareholders from PAT } \\
\text { and retained earnings will be } \\
\text { used only if required. }\end{array}$ \\
\hline $\begin{array}{l}\text { Roles and } \\
\text { Responsibilities } \\
\text { of Board }\end{array}$ & Available & $\begin{array}{l}\text { Mentioned in the Corporate } \\
\text { Governance report }\end{array}$ \\
\hline $\begin{array}{l}\text { Meeting of } \\
\text { shareholders }\end{array}$ & Yes & $\begin{array}{l}\text { Mentioned in the Corporate } \\
\text { Governance report }\end{array}$ \\
\hline $\begin{array}{l}\text { Insider Trading } \\
\text { Policy }\end{array}$ & Yes & $\begin{array}{l}\text { Mentioned in the annual } \\
\text { report }\end{array}$ \\
\hline $\begin{array}{l}\text { Postal Ballot } \\
\text { Voting to pass } \\
\text { resolution }\end{array}$ & Yes & $\begin{array}{l}\text { Mentioned in the annual } \\
\text { report }\end{array}$ \\
\hline Disclosures & Available & $\begin{array}{l}\text { Grasim's has furnished all } \\
\text { disclosures pertaining to } \\
\text { material transactions, details } \\
\text { of director seeking } \\
\text { appointment, financial } \\
\text { disclosures, management } \\
\text { discussion report }\end{array}$ \\
\hline $\begin{array}{l}\text { Non Mandatory } \\
\text { clauses }\end{array}$ & $\begin{array}{l}\text { In } \\
\text { Compliance }\end{array}$ & $\begin{array}{l}\text { Grasim's has a section } \\
\text { which speaks about non } \\
\text { mandatory compliances } \\
\text { being followed such as } \\
\text { separate office for NED, } \\
\text { Shareholders Rights, } \\
\text { quarterly, half yearly and } \\
\text { annual financial reports are } \\
\text { published in newspapers, } \\
\text { separate post of chairman } \\
\text { and MD, Reporting on } \\
\text { internal auditors and have } \\
\text { un-qualified financial } \\
\text { statements }\end{array}$ \\
\hline $\begin{array}{l}\text { Shareholder } \\
\text { Information }\end{array}$ & $\begin{array}{l}\text { Available } \\
\text { (In Detail) }\end{array}$ & $\begin{array}{l}\text { Grasim has provided the } \\
\text { shareholder information in } \\
\text { its annual report }\end{array}$ \\
\hline
\end{tabular}

\begin{tabular}{|c|c|c|}
\hline $\begin{array}{l}\text { Meeting of } \\
\text { Independent } \\
\text { Directors }\end{array}$ & Yes & $\begin{array}{l}\text { Grasim has mentioned the } \\
\text { details of the directors who } \\
\text { attended the meeting along } \\
\text { with date etc. }\end{array}$ \\
\hline $\begin{array}{l}\text { Women } \\
\text { Directors }\end{array}$ & $\begin{array}{l}\text { Yes (Non- } \\
\text { Executive) }\end{array}$ & $\begin{array}{l}\text { Grasim has no Women } \\
\text { Independent Director }\end{array}$ \\
\hline $\begin{array}{l}\text { Risk } \\
\text { Management } \\
\text { Committee }\end{array}$ & Yes & $\begin{array}{l}\text { The Companies have } \\
\text { developed and implemented } \\
\text { a Risk Management Policy. } \\
\text { The Policy envisages } \\
\text { identification of risk and } \\
\text { procedures for assessment } \\
\text { and minimisation of risk } \\
\text { thereof. }\end{array}$ \\
\hline $\begin{array}{l}\text { Independent } \\
\text { Audit Process }\end{array}$ & Yes & $\begin{array}{l}\text { Grasim has an independent } \\
\text { Audit process and the } \\
\text { Certificate of compliance is } \\
\text { published in the Annual } \\
\text { Reports }\end{array}$ \\
\hline $\begin{array}{l}\text { Quarterly } \\
\text { Performance }\end{array}$ & Yes & $\begin{array}{l}\text { The quarterly performance is } \\
\text { reported out on the website } \\
\text { and published in leading } \\
\text { newspaper. }\end{array}$ \\
\hline $\begin{array}{l}\text { Investor } \\
\text { Services }\end{array}$ & $\begin{array}{l}28 \\
\text { Complaints } \\
\text { received } \\
\text { and all } \\
\text { were } \\
\text { cleared. }\end{array}$ & $\begin{array}{l}\text { The number of complaints } \\
\text { received by the Grasim Ltd. } \\
\text { were resolved and intensity } \\
\text { was higher in Grasim }\end{array}$ \\
\hline $\begin{array}{l}\text { Quarterly } \\
\text { Compliance } \\
\text { Report }\end{array}$ & No & $\begin{array}{l}\text { No such report is submitted } \\
\text { by Grasim }\end{array}$ \\
\hline $\begin{array}{l}\text { Disclosure of } \\
\text { RPT }\end{array}$ & Yes & $\begin{array}{l}\text { These transactions were } \\
\text { reported in the annual report }\end{array}$ \\
\hline $\begin{array}{l}\text { Minutes of the } \\
\text { meetings }\end{array}$ & $\begin{array}{l}\text { Delivered } \\
\text { to } \\
\text { stakeholder } \\
\text { after the } \\
\text { meeting }\end{array}$ & Yes, it was done. \\
\hline
\end{tabular}

\section{Discussion}

Above table shows various data point for Grasim industries for the financial year 2016-17, with regard to corporate governance. Researcher has highlighted the following points,

- Grasim is complaint with Equity listing and disclosure agreement by SEBI as stated by audit committee of the Corporate Governance Report.

- Number of Board meetings for Grasim was 5 times a year and the gap between meetings did not exceed 120 days.

- Grasim has constituted a panel which looks after the Insider trading rules and regulation and continuously evaluates the code.

- All Non-Mandatory clauses are followed by Grasim's

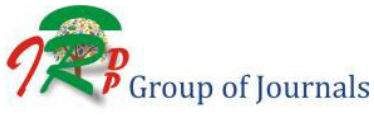


- There are no Independent women directors in Grasim's. They have a Non-Executive women director.

The number of complaints received against Grasim was higher and could point towards the bigger picture of shareholders and stakeholders grievance and redressal and effective management of the complaints. Grasim followed the SEBI guidelines and reported Related Third Party transactions.
- Grasim has sent minutes of the meetings to the Board of Directors as well as to the different stakeholders. The same was not the case with Grasim where there was distribution of the minutes to the stakeholders.

\section{Grasim Industries Ltd (GRASIM IN) - Governance}

Table 2: Data on governance

\begin{tabular}{|c|c|c|c|c|c|c|c|c|c|c|}
\hline $\begin{array}{l}\text { In Millions of INR except } \\
\text { Per Share } \\
\end{array}$ & FY 2008 & FY 2009 & $\begin{array}{r}\text { FY } \\
2010 \\
\end{array}$ & $\begin{array}{r}\text { FY } \\
2011 \\
\end{array}$ & $\begin{array}{r}\text { FY } \\
2012 \\
\end{array}$ & $\begin{array}{r}\text { FY } \\
2013 \\
\end{array}$ & $\begin{array}{r}\text { FY } \\
2014 \\
\end{array}$ & $\begin{array}{r}\text { FY } \\
2015 \\
\end{array}$ & $\begin{array}{r}\text { FY } \\
2016 \\
\end{array}$ & $\begin{array}{r}\text { FY20 } \\
17 \\
\end{array}$ \\
\hline $\begin{array}{l}\text { Governance Disclosure } \\
\text { Score }\end{array}$ & 42.86 & 42.86 & 48.21 & 48.21 & 51.79 & 48.21 & 42.86 & 42.86 & 48.21 & 48.21 \\
\hline \multicolumn{11}{|l|}{ Board Structure } \\
\hline Size of the Board & 9.00 & 10.00 & 11.00 & 12.00 & 12.00 & 12.00 & 12.00 & 12.00 & 12.00 & 12.00 \\
\hline $\begin{array}{l}\text { Unitary or Two Tier Board } \\
\text { System }\end{array}$ & 1.00 & 1.00 & 1.00 & 1.00 & 1.00 & 1.00 & 1.00 & 1.00 & 1.00 & 1.00 \\
\hline $\begin{array}{l}\text { \# Employee Representatives } \\
\text { on Board }\end{array}$ & 0.00 & 0.00 & 0.00 & 0.00 & 0.00 & 0.00 & 0.00 & 0.00 & 0.00 & 0.00 \\
\hline Classified Board System & Yes & Yes & Yes & Yes & Yes & Yes & Yes & Yes & Yes & Yes \\
\hline \multicolumn{11}{|l|}{ Board Independence } \\
\hline \# Non Exec Dir on Board & 7.00 & 9.00 & 9.00 & 10.00 & 10.00 & 10.00 & 10.00 & 10.00 & 10.00 & 10.00 \\
\hline$\%$ Non Exec Dir on Board & 77.78 & 90.00 & 81.82 & 83.33 & 83.33 & 83.33 & 83.33 & 83.33 & 83.33 & 83.33 \\
\hline \# Independent Directors & 5.00 & 6.00 & 6.00 & 6.00 & 6.00 & 6.00 & 6.00 & 6.00 & 6.00 & 6.00 \\
\hline$\%$ Independent Directors & 55.56 & 60.00 & 54.55 & 50.00 & 50.00 & 50.00 & 50.00 & 50.00 & 50.00 & 50.00 \\
\hline CEO Duality & No & No & No & No & No & No & No & No & No & No \\
\hline Independent Chairperson & No & No & No & No & No & No & No & No & No & No \\
\hline Independent Lead Director & No & No & No & No & No & No & No & No & No & No \\
\hline Presiding Director & No & No & No & No & No & No & No & No & No & No \\
\hline $\begin{array}{l}\text { Former CEO or its } \\
\text { Equivalent on Board }\end{array}$ & No & No & No & Yes & Yes & Yes & Yes & Yes & Yes & No \\
\hline \multicolumn{11}{|l|}{ Board \& Exec Diversity } \\
\hline \# Women on Board & 1.00 & 1.00 & 1.00 & 1.00 & 1.00 & 1.00 & 1.00 & 1.00 & 1.00 & 1.00 \\
\hline$\%$ Women on Board & 11.11 & 10.00 & 9.09 & 8.33 & 8.33 & 8.33 & 8.33 & 8.33 & 8.33 & 8.33 \\
\hline $\begin{array}{l}\text { Female Chief Executive } \\
\text { Officer or Equivalent }\end{array}$ & No & No & No & No & No & No & No & No & No & No \\
\hline $\begin{array}{l}\text { Female Chairperson or } \\
\text { Equivalent }\end{array}$ & No & No & No & No & No & No & No & No & No & No \\
\hline $\begin{array}{l}\text { \# Executives / Company } \\
\text { Mgrs }\end{array}$ & 21.00 & 22.00 & 16.00 & 18.00 & 21.00 & 22.00 & 22.00 & 22.00 & 25.00 & 29.00 \\
\hline $\begin{array}{l}\text { CEO or Equivalent } \\
\text { Appointed from Within }\end{array}$ & Yes & Yes & Yes & Yes & Yes & Yes & Yes & Yes & Yes & No \\
\hline \# Female Executives & 0.00 & 0.00 & 0.00 & 0.00 & 0.00 & 0.00 & 0.00 & 0.00 & 0.00 & 2.00 \\
\hline$\%$ Female Executives & 0.00 & 0.00 & 0.00 & 0.00 & 0.00 & 0.00 & 0.00 & 0.00 & 0.00 & 6.90 \\
\hline $\begin{array}{l}\text { Age of the Youngest } \\
\text { Director }\end{array}$ & 41.00 & 42.00 & 43.00 & 44.00 & 45.00 & - & - & - & - & 二 \\
\hline Age of the Oldest Director & 83.00 & 84.00 & 85.00 & 79.00 & 80.00 & - & - & - & - & - \\
\hline $\begin{array}{l}\text { Board of Directors Age } \\
\text { Range }\end{array}$ & 42.00 & 42.00 & 42.00 & 35.00 & 35.00 & - & - & - & - & $=$ \\
\hline
\end{tabular}




\begin{tabular}{|c|c|c|c|c|c|c|c|c|c|c|}
\hline Board Average Age & 64.89 & 65.00 & 64.91 & 62.83 & 63.83 & - & - & - & - & - \\
\hline Board Duration in Years & - & - & 3.00 & 3.00 & 3.00 & 3.00 & - & - & - & - \\
\hline \multicolumn{11}{|l|}{ Board Committees } \\
\hline \# Board Meetings & 5.00 & 5.00 & 5.00 & 4.00 & 6.00 & 5.00 & 4.00 & 5.00 & 6.00 & 5.00 \\
\hline $\begin{array}{l}\text { Board Meeting } \\
\text { Attendance \% }\end{array}$ & 86.67 & 85.11 & 73.58 & 86.36 & 80.55 & 83.33 & 83.33 & 84.62 & 81.94 & 84.61 \\
\hline $\begin{array}{l}\text { Independent Directors Board } \\
\text { Meeting Attendance } \%\end{array}$ & 84.00 & 83.33 & 63.33 & 85.00 & 75.00 & 80.00 & 87.50 & 83.33 & 86.11 & 84.37 \\
\hline $\begin{array}{l}\text { \# Dir Attending Less than } \\
75 \% \text { of Mtgs }\end{array}$ & 2.00 & 2.00 & 6.00 & 2.00 & 5.00 & 2.00 & 1.00 & 3.00 & 2.00 & 3.00 \\
\hline \multicolumn{11}{|l|}{ Audit Committee } \\
\hline Size of Audit Committee & 3.00 & 3.00 & 3.00 & 3.00 & 3.00 & 3.00 & 3.00 & 3.00 & 4.00 & 3.00 \\
\hline $\begin{array}{l}\text { \# Independent Dir on Audit } \\
\text { Cmte }\end{array}$ & 3.00 & 3.00 & 3.00 & 3.00 & 3.00 & 3.00 & 3.00 & 3.00 & 4.00 & 3.00 \\
\hline $\begin{array}{l}\text { \% Independent Dir on Audit } \\
\text { Cmte }\end{array}$ & 100.00 & 100.00 & 100.00 & 100.00 & 100.00 & 100.00 & 100.00 & 100.00 & 100.00 & 100.00 \\
\hline $\begin{array}{l}\text { Independent Audit } \\
\text { Committee Chairperson }\end{array}$ & Yes & Yes & Yes & Yes & Yes & Yes & Yes & Yes & Yes & Yes \\
\hline $\begin{array}{l}\text { \# Non Exec Dir on Audit } \\
\text { Cmte }\end{array}$ & 3.00 & 3.00 & 3.00 & 3.00 & 3.00 & 3.00 & 3.00 & 3.00 & 4.00 & 3.00 \\
\hline Audit Committee Meetings & 6.00 & 6.00 & 7.00 & 7.00 & 6.00 & 7.00 & 8.00 & 6.00 & 8.00 & 6.00 \\
\hline $\begin{array}{l}\text { Audit Committee Meeting } \\
\text { Attendance Percentage }\end{array}$ & 94.44 & 94.44 & 80.95 & 95.24 & 100.00 & 100.00 & 95.83 & 100.00 & 100.00 & 90.00 \\
\hline \multicolumn{11}{|l|}{ Compensation Committee } \\
\hline $\begin{array}{l}\text { Size of Compensation } \\
\text { Committee }\end{array}$ & 0.00 & 0.00 & 0.00 & 0.00 & 0.00 & 0.00 & 3.00 & 3.00 & 3.00 & 3.00 \\
\hline $\begin{array}{l}\text { \# Independent Dir on Comp } \\
\text { Cmte }\end{array}$ & - & - & 一 & - & - & - & 2.00 & 2.00 & 2.00 & 2.00 \\
\hline $\begin{array}{l}\text { \% Independent Dir on Comp } \\
\text { Cmte }\end{array}$ & - & - & 一 & - & - & - & 66.67 & 66.67 & 66.67 & 66.67 \\
\hline $\begin{array}{l}\text { Independent Compensation } \\
\text { Committee Chairperson }\end{array}$ & $\mathrm{n} / \mathrm{a}$ & $\mathrm{n} / \mathrm{a}$ & $\mathrm{n} / \mathrm{a}$ & $\mathrm{n} / \mathrm{a}$ & $\mathrm{n} / \mathrm{a}$ & $\mathrm{n} / \mathrm{a}$ & $\mathrm{n} / \mathrm{a}$ & $\mathrm{n} / \mathrm{a}$ & Yes & Yes \\
\hline $\begin{array}{l}\text { \# Non Exec Dir on Comp } \\
\text { Cmte }\end{array}$ & - & - & - & - & - & - & 3.00 & 3.00 & 3.00 & 3.00 \\
\hline $\begin{array}{l}\text { \# Comp Committee } \\
\text { Meetings }\end{array}$ & - & - & - & - & - & - & - & 2.00 & 3.00 & 3.00 \\
\hline $\begin{array}{l}\text { Compensation Committee } \\
\text { Meeting Attendance \% }\end{array}$ & - & - & - & - & - & - & - & 83.33 & 88.88 & 77.78 \\
\hline $\begin{array}{l}\text { Outside Compensation } \\
\text { Advisors Appointed } \\
\end{array}$ & No & No & No & No & No & No & No & No & No & No \\
\hline \multicolumn{11}{|l|}{ Nomination Committee } \\
\hline $\begin{array}{l}\text { Size of Nomination } \\
\text { Committee }\end{array}$ & - & - & 一 & - & - & 0.00 & 3.00 & 3.00 & 3.00 & 3.00 \\
\hline $\begin{array}{l}\text { \# Independent Dir on Nom } \\
\text { Cmte }\end{array}$ & - & - & - & - & - & - & 2.00 & 2.00 & 2.00 & 2.00 \\
\hline $\begin{array}{l}\% \text { of Ind Directors on } \\
\text { Nomination Committee }\end{array}$ & - & 一 & 一 & - & - & - & 66.67 & 66.67 & 66.67 & 66.67 \\
\hline $\begin{array}{l}\text { Independent Nomination } \\
\text { Committee Chairperson }\end{array}$ & $\mathrm{n} / \mathrm{a}$ & $\mathrm{n} / \mathrm{a}$ & $\mathrm{n} / \mathrm{a}$ & $\mathrm{n} / \mathrm{a}$ & $\mathrm{n} / \mathrm{a}$ & $\mathrm{n} / \mathrm{a}$ & $\mathrm{n} / \mathrm{a}$ & $\mathrm{n} / \mathrm{a}$ & Yes & Yes \\
\hline $\begin{array}{l}\text { \# Non Exec Dir on Nom } \\
\text { Cmte }\end{array}$ & - & - & 一 & - & - & - & 3.00 & 3.00 & 3.00 & 3.00 \\
\hline \# Nom Cmte Meetings & - & - & - & - & - & - & - & 2.00 & 3.00 & 3.00 \\
\hline $\begin{array}{l}\text { Nomination Committee } \\
\text { Meeting Attendance } \\
\text { Percentage }\end{array}$ & - & - & - & - & - & - & - & 83.33 & 88.88 & 77.78 \\
\hline $\begin{array}{l}\text { CSR/Sustainability } \\
\text { Committee }\end{array}$ & No & No & No & No & No & Yes & Yes & Yes & Yes & Yes \\
\hline
\end{tabular}




\begin{tabular}{|c|c|c|c|c|c|c|c|c|c|c|}
\hline Board \& Exec Activities & & & & & & & & & & \\
\hline $\begin{array}{l}\text { Non-Executive Director with } \\
\text { Responsibility for CSR }\end{array}$ & No & No & No & No & No & No & No & No & No & No \\
\hline $\begin{array}{l}\text { Executive Director with } \\
\text { Responsibility for CSR }\end{array}$ & No & No & No & No & No & No & No & No & No & No \\
\hline $\begin{array}{l}\text { Executive Compensation } \\
\text { Linked to ESG }\end{array}$ & No & No & No & No & No & No & No & No & No & No \\
\hline $\begin{array}{l}\text { ESG Linked Compensation } \\
\text { for Board }\end{array}$ & No & No & No & No & No & No & No & No & No & No \\
\hline $\begin{array}{l}\text { Clawback Provision for } \\
\text { Executive Compensation }\end{array}$ & No & No & No & No & No & No & No & No & No & No \\
\hline $\begin{array}{l}\text { Chg of Ctrl Benefits/Golden } \\
\text { Parachute Agreements }\end{array}$ & No & No & No & No & No & No & No & No & No & No \\
\hline Shareholder Rights & & & & & & & & & & \\
\hline $\begin{array}{l}\text { Dual Class Unequal Voting } \\
\text { Rights - Common Shares }\end{array}$ & No & No & No & No & No & No & No & No & No & No \\
\hline AGM Voting Results & & & & & & & & & & \\
\hline Auditor Ratification & $\mathrm{n} / \mathrm{a}$ & $\mathrm{n} / \mathrm{a}$ & $\mathrm{n} / \mathrm{a}$ & $\mathrm{n} / \mathrm{a}$ & $\mathrm{n} / \mathrm{a}$ & $\mathrm{n} / \mathrm{a}$ & $\mathrm{n} / \mathrm{a}$ & $\mathrm{n} / \mathrm{a}$ & Yes & Yes \\
\hline $\begin{array}{l}\text { Auditor Ratification Number } \\
\text { of Votes - FOR }\end{array}$ & - & - & - & - & - & - & - & - & $\begin{array}{r}5,40,5 \\
0,000 . \\
00\end{array}$ & $\begin{array}{r}45,43, \\
75,008 \\
.00\end{array}$ \\
\hline $\begin{array}{l}\text { Auditor Ratification Number } \\
\text { of Votes - AGAINST }\end{array}$ & - & - & - & - & - & - & - & - & $\begin{array}{r}2,19,1 \\
67.00\end{array}$ & $\begin{array}{r}1,59,6 \\
44.00\end{array}$ \\
\hline
\end{tabular}

\section{Data Analysis}

The data pertaining to governance of Grasim industries has been procured from Bloomberg. This shows data for last 10 years related to board governance and disclosure in Grasim. First and foremost important factor is governance disclosure score which has been more or less same in these 10 years. It was 42.86 in FY 2008 and it was reported to be 48.21 in FY 2017. It was highest as 51.79 in FY 2012.

Size of the board has increased from 11 to 12 from FY 2010 to 2011 and it has been maintained at the same level since then. Presence of non-executive director has been increased on the board from FY 2011 to make it at $83.33 \%$. Independent directors have also increased to 6 in the year 2009 and since the number of independent directors is 6 making it as $50 \%$ of the directors of Grasim are independent. CEO duality is also missing which is welcome news for the shareholders of the company.

There has been a woman as the director and there is no change in the number since FY 2008. There has been drop in the women director in terms of percentage as in FY 2008 total board size was 9 , so women director stood at $11 \%$ while in FY 2017 the board size increased to 12 causing a decrease in the percentage of women director from $11 \%$ to $8 \%$.The appointment of CEO or equivalent is from the within.

The number of board meetings is varying from 4,5 and 6 in these 10 years period of study. The attendance of the board director, and independent directors has been more than $80 \%$ barring a FY 2010. Size of the audit committee is of 3 members while in the year 2016 there were 4 members. The number of independent director on the board has been $100 \%$ which means that the audit is being done by independent directors.

Compensations committee and nomination committee of Grasim was formed only in the year 2014 with 3 members forming the compensation committee. There have been $67 \%$ of directors as independent directors on the compensation and nomination committee of the Grasim Industries. The report also shows that the non-executive director of the co has not been overall responsibility of CSR.

Table 3. Compliance of Grasim Industries

\begin{tabular}{|l|l|l|}
\hline S. No & $\begin{array}{l}\text { Listing Obligations and } \\
\text { disclosure Requirement }\end{array}$ & $\begin{array}{l}\text { Compliance } \\
\text { Status }\end{array}$ \\
\hline 1. & Applicability & Complied \\
\hline 2. & Shareholder's Right & Complied \\
\hline 3. & Disclosures \& Transparency & Complied \\
\hline 4. & Responsibility of the Board & Complied \\
\hline
\end{tabular}

After Studying the Annual Report, it is evident that GRASIM is following the Corporate Governance of SEBI. As provided under Securities and Exchange Board of India (Listing Obligations and Disclosure Requirements) Regulations, 2015, the Board of Directors and therefore the Senior force have affirmed compliance with the Code of Conduct of the Board of Directors and Senior Management for the year ended 31st March 2017. 
In terms of the Listing Agreement, the Board has laid down a Code of Conduct for all Board Members and senior force of the corporate. Also, they're very transparent for his or her financial records. They need disclosed the contingent liabilities, assets and every one accounts related information. The Annual Accounts of the subsidiary Companies and related detailed information are made available to the Shareholders of the holding and subsidiary companies, seeking such information at any point of your time.

\section{Conclusion}

The integrity of the corporation, financial institutions and markets is necessary for the health and stability of the economy. In the era of globalization, Corporate Governance has become indispensable "The proper governance of the company will become as crucial to the world economy as the proper governing of countries strong corporate governance produces good social progress. The two go together."

Corporate Governance needs to encompass various aspects like political, economic, administrative and social in order to build trust in the organization. The board must work in the interest of all stakeholders with no partiality towards any group. The entire process is involved in protecting the rights of the shareholders by keeping in mind the financial health of the organization and the health of the society at large. With increasing cross border integration there is a great need for corporate governance.

Corporate governance aims at safeguarding the interest of the investor, especially those of small investors, by providing them sufficient information. The information provided should help the investor in taking a well informed decision. It also includes the information which should be provided to other people who have some interest in the company, either directly or indirectly. Employees should be provided with the information such as profit of the company, performance of the employees so that they can relate the bonus declared with the amount of profit and payment with the performance, respectively.

Grasim Industries Limited is committed to the adoption of best governance practices and its adherence in the true spirit, at all times. Their governance practices are self-driven, reflecting the culture of the trusteeship that is deeply ingrained in our value system and reflected in our strategic growth process. Grasim Industries annual reports have been analysed by researcher and company has been following the guidelines which have been raised by regulatory bodies.
The study concludes that company is following the rules in reference to corporate governance to make sure transparency, disclosures and reporting that conforms fully to laws, regulations and guidelines, and to market ethical conduct throughout the Organization, with the first objective of enhancing shareholders value, while being a responsible corporate citizen. The corporate is committed to conforming to the very best standards of corporate governance within the Country. It recognizes that the Board is accountable to all or any shareholders whom each member of the Board owes his/her first duty for shielding and furthering the interest of the corporate. To prove this, they need ranked 2nd for Best Corporate Governance Practices in Asia-Pacific by IR Global Rankings. Also, ranked excellent company in corporate governance practices in basic materials industry.

\section{References}

[1] Adams, R. B., \& Mehran, H. (2012). Bank board structure and performance: Evidence for large bank holding companies. Journal of financial Intermediation, 21(2), 243-267.

[2] Baysinger, B. D., \& Butler, H. N. (1985). Corporate governance and the board of directors: Performance effects of changes in board composition. Journal of Law, Economics, \& Organization, 1(1), 101-124.

[3] Bloomberg

[4] Business week, November 25, 1996, pg.84

[5] Chahine Salim, Safieddine Assem (2009). Is corporate governance different for the Lebanese Banking System, Journal of management and governance, 15(1), 207-226

[6] Corporate Governance by Anthony Williams

[7] Corporate Governance by P.V. Sarma S. Rajam, Kanishka Publishers, Distributors, New Delhi

[8] Cullinan, C. P., \& Sutton, S. G. (2002). Defrauding the public interest: a critical examination of reengineered audit processes and the likelihood of detecting fraud. Critical Perspectives on Accounting.

[9] http://www.iosrjournals.org/iosr-jbm/papers/Vol6issue3/A0630111.pdf

[10] http://www.oecd.org

[11] M. Mehta and A. Chandani, Empirical Study of Corporate Governance W.R.T. Board of Directors Practices Among Top Five Indian Corporate Sector, International Journal of Management, IT and Engineering, 3(5), (2013), 262-274.

[12] Mehta, M., Neeraja, B., \& Chandani, A. (2014). Women CEOs and financial performance of banks: An empirical research of Indian private sector banks. Management-Journal of Contemporary Management Issues, 19(1), 231-246.

[13] Mousa F AI Manaseer , Riyad Mohamad A1, Mohamad A , "The impact of corporate governance on the performance of Jordian Banks" , European Journal of scientific research , Euro journal Publishing , 2012

[14] https:// www.ey.com/ Publication/vwLUAssets / EY- sebi- listingobligations- and- disclosure- requirements- amendment- regulations2018/\$File/EY-sebi-listing-obligations-and-disclosure-requirementsamendment-regulations-2018.pdf accessed on 04.09.18

[15] https://www.sebi.gov.in/sebi_data/attachdocs/1441284401427.pdf accessed on 04.09 .18 